\title{
A Comparative Analysis of the Implementation of Freedom of Association and Collective Bargaining Principles in Post-Apartheid South Africa and The U-nited States of America in Respect of ILO Standards
}

\author{
Akhabue A. Okharedia \\ University of South Africa
}

This article attempts to investigate the extent to which post-apartheid South Africa and United States of America have implemented freedom of association and collective bargaining principles in workplace environment in respect of ILO standards. The investigation shows that South Africa has done better than USA in the implementation of freedom of association and collective bargaining principles. Post-apartheid South Africa has well-structured legal framework to promote and implement freedom of association and collective bargaining principles when compared with USA. This paper highlights the precarious state of trade unions in the USA in implementing freedom of association and collective bargaining process in the workplace environment.

\section{INTRODUCTION}

The International Labour Organisation (ILO) 1948 Convention on Freedom of Association (No 87) and the Convention on Collective Bargaining of 1949 (No. 98) seems to be one of the most important of all the ILO Conventions and the one most valued by workers all over the world. It provides that workers and employers without distinction whatsoever shall have the right to establish and join organisations of their own choosing. ${ }^{1}$

It also provides for guarantees permitting those organisations and any federations that may be establish to carry on their activities without interference from public authorities. Member states ratifying the convention are expected to take all necessary and appropriate measures to ensure that workers and employers may exercise freely the right to organize. ${ }^{2}$

Convention No. 98, which supplements this standard, is designed to protect workers against acts of anti-union discrimination, to safeguard workers and employers organisations from mutual interference, and to promote voluntary negotiation between management and labour. However, in recent years, the ILO has adopted more labour law standards to support both the Convention on Freedom of Association and the Convention on Collective Bargaining. The new labour law standards include the Workers Representatives Convention (No. 135), and Recommendation (No. 143) of 1971.Their main purpose is to ensure that workers representatives in enterprises are effectively protected against any prejudicial act based on their status or activities as workers representatives or on their union activities. In the same vein 
to provide those facilities which would enable those representatives to carry out their functions promptly and efficiently ${ }^{3}$. The new Conventions also include the Rural Worker's organisations Convention (No. 141) and Recommendation (No. 149) of 1975, which states clearly that all categories of rural workers are entitled to establish and join organisations of their own choosing, and provide that measures must be taken to facilitate the establishment and growth of strong and independent organisations of their choice.

It is also interesting to note in the introductory part of this paper that in 1998, the ILO adopted the Declaration on Fundamental Principles and Rights at Work that defined the Core Conventions of decent work. Among the four fundamental principles and rights at work are freedom of association and the effective recognition of the right to collective bargaining derived from ILO Convention 87 and 98 respectively and these are often referred to as Freedom of Association (FOA) conventions and ILO members are required to respect them, even in situations where they have not ratified them. ${ }^{4}$ In light of the above background, this paper attempts to examine how South Africa in its post-apartheid era has complied with ILO Standard when compared with the way USA has recognized and implement - ILO labour standards in terms of freedom of association and Collective bargaining processes.

\section{THE SOUTH AFRICAN EXPERIENCE OF FREEDOM OF ASSOCIATION AND COLLECTIVE BARGAINING IN THE WORKPLACE}

In 1995, South Africa enacted the Labour Relations Act No 66 (hereinafter the 'LRA') and Section 4 of this Act confers on every employee the right to participate in the formation of a trade union and to join a trade union. ${ }^{5}$ Once a member, an employee has the right to participate freely in trade union lawful activities and to participate in the election of its office-bearers and to be eligible for appointment as an office-bearer, and to assist any other employee or an office-bearer of a trade union to exercise such right. ${ }^{6}$ The LRA further prohibits employers from discriminating against employees or applicants for employment for exercising any of the rights in section 4 (2) (a) and (b) and in particular, they may not require employees or persons seeking employment not to be members of a particular trade union or unions generally, or act to their prejudice for past, present or anticipated union members. However, it should also be noted that employee's rights of association are limited by subjecting them to agency shop and close-shop agreements ${ }^{7}$

An agency shop agreement is one in terms of which the employer is required to deduct an agreed agency fee from the wages of its employee who are not members of a trade union, and such monies are to be paid into a separate account administered by the trade union concerned to protect the socio-economic interests of employees. ${ }^{8}$ In terms of section 25 of the LRA, a union may be the beneficiary of an agency shop agreement only if it is registered and if it alone, or together with another union or unions with which it acts jointly, represents a majority of employees in a workplace or sector or area. The fees over paid by non-members must not exceed the subscription paid by the union's members and contributors must not be forced to become members of the union. This part of the LRA reflects the freedom of association opened to an employee and it shows the degree to which an employee has the choice to make, to join a union or not to join in South Africa. ${ }^{9}$ In terms of closed shop agreement, all employees who agree to be covered by the agreement are required to join a particular trade union of their choice. In terms of section 26 of the LRA, only a registered trade union representing a majority of employees in a workplace or sector can enter a closed-shop agreement.

In terms of international labour standards on freedom of association, the South Africa LRA agrees with Article 2 of the ILO international labour standard convention in terms of section 4, 5 and 6 of the LRA. In addition to the above sections, some case law will be examined here to assess the extent the issue of freedom of association has been allowed in a workplace environment in South Africa. In the case of IMATU and others $v$ Rustenburg Transitional Council ${ }^{10}$, the Labour Court fully supported section 4 of the LRA on the freedom of association in terms of ILO standards. In this case, on the $27^{\text {th }}$ of January 1998, the respondent, a local council operating under the local Government Transition Act 209 of 1993, adopted a resolution in terms of which, inter alia, it determined that an employee on job level 1-3 should not be allowed to serve in executive positions of trade unions or be involved in trade union activities. This was 
followed by an objection by the first applicant, which is the trade union and because of this objection, it was deleted from the resolution, but the other aspect of the resolution was left unchanged. In view of the fact that the union was not satisfied with the remaining part of the resolution, the union launched proceedings that culminated in the claim for an order to set the resolution aside as a contravention of the LRA and the Bill of Rights in the Constitution. (Section 18) ${ }^{11}$

In terms of the council's job-grading system, the job levels referred to in this resolution comprise the senior executive and management officials of the council. The incumbents perform the functions traditionally assigned to top management of an organization. They give advice and make recommendations to the councilors, who are ultimately responsible for formulating policy, and ensuring that the council's resolutions are carried out properly. For this purpose, they must direct, motivate and where necessary, discipline the members of staff under their control in the departments into which the administration of the council is divided.

For them to do a proper work they must enjoy the trust and confidence of the council and perhaps more than any category of employee, must place the interest of the council above their own and above those of third parties.

The council contended that those senior officials could not simultaneously discharge their obligations as employees and sit on the branch executives of the union. In its reply to the statement of care, it gives three reasons for taking this stance. The first reason is that officials have access to confidential information such as levels of maximum increases to which the respondent might agree in wage negotiations that they would be duty bound to disclose to the first applicant if they served on its executive. The second reason is that they are required to initiate or conduct disciplinary hearings against employees, and should the accused be a member of the union, the membership of the executive of the first applicant would at the very least, be seen to compromise the fulfilling of the disciplinary duties. The third reason is that they might because of their membership of the union executive, find themselves in the position in which they were 'unable or unwilling to fulfill essential tasks require of them'.

In view of the above facts, the court held that although the respondent had not expressly contended that members of management would commit a breach of their duty of fidelity by the very act of accepting a position on the executive of a union, it was prepared to accept for purposes of judgment that the issue could be properly considered. When employees joined a trade union they, committed themselves to a body, the primary object of which is to maximize the benefits its members derive from their employment. In the pursuit of this, unions extracted what they could from the employer by negotiation. With this passage of time, unions had been recast from their adversarial role into partners in corporate enterprise.

However, conflict between capital and labour remained. By committing themselves to unions, therefore, employees go over to the opposition. This could amount to a breach by the employees concerned of their duty of fidelity towards their employer. Dismissal in such circumstances might be lawful under the common law. In the case of senior employees, greater loyalty could be expected. A senior employee who took up a leadership role in a union was placed in the vanguard of the struggle against the employer. At common law, therefore, a senior employee was not permitted to join a union and this negate ILO standard. However, it is interesting to note that the Constitution of South Africa has granted every employee the right to join and hold office in a union and to participate in its activities. In the same vein, the LRA as recently amended has complied with the Constitution and in the same vein, gives opportunity to all employees the rights to participate in any lawful union activities.

\section{The Collective Bargaining Process in South Africa}

In broad terms, the process of collective bargaining in South Africa can be defined as the process in which employers and employees collectively seek to reconcile their conflicting goals through a process of mutual accommodation. ${ }^{12}$ While its dynamic is demand and concession, its ultimate objective is agreement. Its main feature is that there is willingness on each side not only to listen to the representations of the other, but also to abandon fixed positions where possible so as to find a common ground for agreement. This is clearly illustrated in the case of Metal and Allied Workers Union V Hart Ltd. 
Today, in South Africa, the heart of employment relations is the collective bargaining process and institutions involved have been charged by the LRA to promote the process. These institutions are the Commission for Conciliation, Mediation and Arbitration (therein after 'CCMA'), workplace forums, bargaining Councils and statutory councils. ${ }^{13}$

The above forums are structured through legislation or by agreement between unions and employers. The forums may be a permanent institutionalized structure or temporary arrangements to facilitate bargaining of the annual wage agreement in a specific enterprise. Finnemore (1999) argues that if there is to be more stability in collective bargaining, at the very least, the forums and levels at which it takes place should be accepted by the parties. ${ }^{14}$ At this juncture, an attempt will be made to examine how South African Courts have encouraged collective bargaining through trade union in terms of promoting freedom of association in respect of ILO standards.

The first case law that comes to our mind in respect of the above issues is the case of Safcor Freight (Pty) Ltd $v$ South African Freight and Dock Workers Union. ${ }^{15}$

In this case, the appellant was a freight forwarding business, employing more than 1100 employees throughout South Africa. The present dispute concerns the Durban operation where the appellant employed 277 employees of whom 31 were managerial employees. In terms of collective agreement entered into with the respondent, the latter union was recognized as the representative of the appellant's members within the bargaining unit for the purpose of collective bargaining for so long as the union maintained a membership level of $51 \%$ of the employees within the workplace. The respondent represented about $40 \%$ of the employees working at the Durban operation. As the appellant did not challenge the union's level of representation, it was inferred by the employees that the union represented made up more than $50 \%$ of those employees who qualified to be members of the union and the bargaining unit.

The parties subsequently agreed to a wage increase of $6.75 \%$ per annum in respect of persons earning below R6000 per month. On the ground that the increase was extended and applied to the employees who did not fall within the bargaining unit, the union applied to the Labour Court for a declaratory that the appellant was in breach of sections 5(1), 5(2) (a) (ii) and (iii), 5(2) (c) (i), 5(3) and 5(4) of the LRA, that the award of increased remuneration to the non-bargaining unit employees was inconsistent with sections 9 and 23 of the Constitution. It also asked the court either to reverse the payment of the increased amounts or to grant the bargaining unit employees a similar increase.

The Labour Court held that the award of a wage increase by the appellant to certain of its nonunionised employees was discriminatory and prejudicial in violation of section 5 of the LRA and sections 9 and 23 of the Constitution based on the above facts, there was an appeal in which the bone of contention was whether the appellant through its conduct, infringed the protections accorded by the right to freedom of association enshrined in chapter 11 of the LRA. The Labour Court of appeal found that by declaring the award of increased remuneration it is inconsistent with section nine (equality) and section 23 of the South African Constitution.

In terms of Section 5 of the LRA, it contains a prohibition against "anti- union discrimination". The court found on the facts before it that the bargaining unit employees were Prima facie prejudiced or discriminated against because of their membership of the union, while the non-union employees were advantaged in exchange for not exercising their right to join the union. The cause of disagreement was whether that discrimination was unfair or unjustifiable, and whether the advantaging of the non-union members was fair and justifiable in these circumstances. The Labour Appeal Court found the appellants conduct not to be justifiable.

The rationale for discussing this case is to highlight how South African Courts have supported and promote freedom of association. The Courts are of the view that it is unfair to discriminate against employees because of their membership of a union. This emphasize the fact that employees in any organization can form or join a union of their choice, thus there is freedom of association in their work place. Both the LRA and the Constitution support this. 


\section{UNITED STATES OF AMERICA EXPERIENCE OF FREEDOM OF ASSOCIATION AND COLLECTIVE BARGAINING PROCESS}

Unfortunately, USA has not ratified ILO Conventions 87 and 98 on freedom of association and collective bargaining when compared with South Africa that has ratified and implemented the Conventions. The ILO considers these conventions Constitutional in nature and effect, thus obligating all member countries to comply with them regardless of ratification. ${ }^{16}$ The US government has been criticized by Human Rights watch reports for espousing support for freedom of association in law but failing to provide the regulatory oversight needed to exercise that prerogative (Dawkins, 2012, ${ }^{17}$ Compa, 2000). ${ }^{18}$ In fact, the US government has acknowledge to the ILO that there were circumstances wherein its industrial relations system failed to fully protect the rights of workers to organize and bargain collectively (Gross, 2003) ${ }^{19}$. Historical labour reports shows clearly that US firms and legislators continue to resist pressure from ILO and they reject what they perceive to be outside interference in the US domestic affairs.

Section 7 of the National Labour Relations Act (NLRA) ${ }^{20}$ states clearly that workers can 'form, join or assist labour organisations' and engage in concerted activities for their mutual aid and benefit and section 8 prohibits unfair labour practices. This is quite similar to section 4, 5, 6 and 185 of the South Africa LRA. However, in the case of US, despite the above sections, the Human Rights Watch report documents the precarious state of trade union rights and the widespread anti-union discrimination (Compa, 2000). ${ }^{21}$ In US when workers vote to form labour union as permitted by section 7 of the NLRA, it is not unusual for the unionized firm already existing to simply shut down or relocate (Bronfenbrenner, $2001{ }^{22}$ Frontline, 2004). ${ }^{23}$ This hardly occur in the case of post-apartheid South Africa where employers continue to stridently oppose freedom of association through court filings to reinterpret labour law and challenge its fairness (Kleiner,2001). ${ }^{24}$

The research work of Mehta and Theodore $(2005){ }^{25}$ has shown difficulties in an analysis of National Labour Relations Board (NLRB) data on election petitions filed by unions in metropolitan Chicago in 2002. They found that 30 percent of the involved firms fired pro-union workers, 49 percent threatened to close a worksite if the union prevailed, and 51 percent coerced workers into opposing unions with bribery or favoritisms. All these threatened employees in US in forming a union or joining a union of their choice, thus limiting their freedom of association. There are also structural problems in the union organizing process in the US, such as denying union representatives access to the workplace and numerous delays in elections and rulings on various unfair labour practices. It has been argued that despite the fact that most American workers prefer collective means of workplace representation to approaching the employer individually (Freeman and Rogers, 2006), ${ }^{26}$ US labour law has become so ossified and ineffectual as a means of workplace protection that the ILO Committee on Freedom of Association has ruled that in several important respects US labour practices do not conform to international labour right standards (Gross, 2009, ${ }^{27}$ Dawkins, 2012 ${ }^{28}$ ). This is of great concern to Human Rights watch, the ILO and other International Business Entities. For example, an international coalition of institutional investors managing 757 billion US dollars sent a letter to its various firms indicating the freedom to form or join a union of one's choice or not, and to bargain collectively for the terms of one's employment, are fundamental human rights that this global investors recognized and respect and asking those firms in the US how they intend to protect labour rights and the freedom of association in their workplace (Domini Social Investments, $2009^{29}$ ). This was of a particular concern in view of how US firms have promoted freedom of association and collective bargaining processes in the past.

\section{Collective Bargaining in USA}

In 2007, the ILO Committee on Freedom of Association ruled on a complaint brought by public employees in North Carolina over restrictions on their collective bargaining rights under State law. The cause of disagreement was that the employees had chosen representation by the United Electrical workers union, but the state refused to bargain with them. It was North Carolina State policy for the Government Department and other entity to use their discretion to decide whether to bargain with public employees. 
This shows that the public sector was not friendly with employees who exercise their freedom of association to join trade union through which they could bargain collectively with their respective employers, in view of this, the public employees in North Carolina had to complain to the ILO Committee on the Freedom of Association (CFA) to intervene on their plights in respect of the state refusal to bargain with them. The CFA after assessing the situation and the facts of this case, emphasized and concluded that the right to bargain freely with employers, including the various government departments with respect to conditions of work of public employees constitutes an essential element in freedom of association, and trade unions should have the right, through collective bargaining or other lawful means, to seek to improve the living and working conditions of those whom the trade unions represent. The public authorities should refrain from any interference, which would restrict this right or impede the lawful exercise thereof.

In the case of South Africa, in the post-apartheid era, the above experience of public employees in North Carolina would not have occurred because employees in both the public and private sectors are protected in terms of their freedom of association and their bargaining rights either individually or collectively by the LRA of 1995 as amended.

The South Africa Government has successfully established the commission for Conciliation Mediation and Arbitration (CCMA) where employees can challenge infringement on their rights at no cost especially at the conciliation or mediation levels. The CCMA has been a watchdog in protecting all the rights of employees in both the public and private sectors.

In 2005, the New York states "Taylor Law" prohibits strikes by public employees and it imposes fines and imprisonment on strikers who went beyond affordable limits on collective bargaining rights. This case arose from a 3-day New York City subway strike in 2005. The ILO Committee on Freedom of Association viewed this law as unfair to public employees and argued that "by restricting the right to strike by employees in this transportation sector, the "Taylor Law" does not conform with the principles of freedom of association "and requested the government to take steps aimed at bringing the law into conformity with Committee on Freedom of Association principles". The Committee also found that the heavy fines and imprisonment of union leaders likewise violated CFA principles, and called for compensatory measures. ${ }^{30}$

In South Africa, the above law will be difficult to be enacted and implemented mainly because Section 64 of the LRA clearly spelt out the rights of employees to strike provided it is a protected strike where the employees have compiled with the requirements to strike Section 64 also spelt out employer's recourse to lock out and the conditions in which employers can exercise their rights to lock out action. It is not easy for an employer to prohibit employees from going on strike when the employees have fulfilled all the requirements for them to go on strike action. In recent time, North Carolina employees union turned to the Inter - American Commission for Human Rights (IACHR) to help them resolve the conflict between North Carolina's prohibition on collective bargaining and freedom of association protections in the American Declaration of the Rights and Duties of Man and the American Convention on Human Rights. ${ }^{31}$

In the case of South Africa, it will be difficult to experience the above situation, mainly because the employees in both the public and private sectors do not only rely on the South African Human Right Commission to protect their freedom of association and their rights to collective bargaining, they also relay on the LRA which is an Act of parliament and universally applicable to all employees and employers in South Africa except those in (a) National Defence Force (b) National Intelligent Agency and (c) the South African Secret Service

\section{CONCLUDING REMARKS}

From the above discussion, South Africa has a well-structured legal framework to promote freedom of association and collective bargaining forum to help employees to enjoy their work environment and at the same time meet up with ILO labour standards. In recent time, this has gone a long way to create certainty and a cordial atmosphere for both employers and their employees in South Africa labour market. 
However, much still need to be done in South Africa to maintain ILO standards. In the US, federal law severely restricts subjects of bargaining in ways that conflict with international standards - federal employees cannot bargain over economic issues such as pay and benefits, for example. At the state level, some states respect the right to organize and bargain collectively and allow wide scope for subjects of bargaining in terms of ILO Standards. Good enough, the state of Wisconsin is one of the above states. Unfortunately, the same state of Wisconsin has joined more than 20 other states, like North Carolina, that now prohibit collective bargaining coupled with the violation of international human rights norms. ${ }^{32}$ As Lance Comps (2012) has pointed out, "it is essentially stressing that Wisconsin, historically a "laboratory of democracy" in the American system with a strong record of honoring workers' rights of association, organizing, bargaining, and one of the first states to grant public employees the right to bargain collectively, moved into the camp of international labour rights violators. Other states in U.S still impose harsh new restrictions on public employees bargaining rights and freedom of association. This must be discouraged to allow public employees to enjoy their dignity, equality and democracy in their workplace environment.

\section{ENDNOTES}

1. Mahaim, E, Origin of ILO

2. See Report of the International Labour Organisation to the United Nations (1952) Geneva: ILO and the 6th Report of the International Labour Organisation to the UNO in 1953

3. Ramm, T, Making of Labour Law in Europe: A Comparative study from ILO Convention 87 and 98 respectively and these are often referred to as Freedom of Association (FOA)

4. See Human Rights Watch, 2010.

5. Du Plessis and Fouche: A Practical Guide to Labour Law

6. Section 4 of the LRA states that (1) every employee has the right - (a) To participate in forming a trade union or federation of trade unions; and (b) every member of a trade union has the right subject to the constitution of that trade union - (a) to participate in its lawful activities; (b) to participate in the election of any of its office bearer or officials or trade union representative; (c) to stand for election and be eligible for appointment as an office bearer or official and, if elected or appointed, to hold office and (d) to stand for election and be eligible for appointment as a trade union representative and, if elected or appointed to carry out the functions of a trade union representative in terms of this act or any collective agreement union or workplace forum; (II) participating in forming a trade union or federation of trade union or establishing a workplace forum

7. Du Toit et. al Labour relations Act, 1995

8. See s 5 of LRA, states clearly the protection of employees and person seeking employment. Section 5(1) state that: No person may discriminate against an employee exercising any right conferred by this Act. (2) without limiting the general protection conferred by subsection (1), no. person may do, or threaten to do, any of the following - (a) require an employee or a person seeking employment (i) not to become a member of a trade union or workplace forum (iii) to give up membership of a trade union or workplace forum (b) prevent an employee or a person seeking employment from exercising any right conferred by this Act or from participating in any proceedings in terms of the LRA or (c) prejudice an employee or a person seeking employment because of his past membership of a trade union or workplace forum.

9. Ibid

10. ILJ (2005)

11. De Waal, J. et. al, The Bill of Rights Handbook, 1999

12. See LRA, p. 25

13. Grogan, J. Workplace Law

14. Finnemore, M, Introduction to Labour Relations in South Africa (1999)

15. Labour Court Judgement 2012

16. See Human Rights Watch, 2010

17. Dawkins C.E, Corporate Citizenship, Labour Union and Freedom of Association

18. Compa, see Humana Rights Watch (2000).

19. Gross J.A (Ed) Workers Rights as Human Right, p 1-23

20. US, National Labour Relations Act 29, 151-169 (1935) 
21. Ibidi Compa

22. Bronfenbrenner, K,Washington D.C. (2001)

23. Frontline, Wal-Mart (2004)

24. Kleiner, JLR (2001)

25. Melita, C, \&Theodore, N (2005)

26. Freeman, \& Rogers ILR (2006)

27. Gross \& Compa (2009)

28. Dawkins (2012)

29. Domini Social Investment (2009) News Archive

30. Complaint Against the United States (Case no.2741) Report of the Committee on Freedom of Association (2011)

31. Ibid, p 378

32. Ibid. Human Rights Watch

\section{REFERENCES}

Bronfenbrennemerk, K. (2001). Uneasy terrain: The impact of capital mobility on workers, wages and union organizing. Washington, DC. US Trade Deficit Commission.

Compa, L.A. (2000). Unfair Advantage : Workers' Freedom of Association in the United States under international human rights standards. Human Right.

Dawkins, C. E. (2012, July). Laboured Relations: Corporate Citizenship, Labour Unions and Freedom of Association. Business Ethics Quarterly, 473-500.

De Waal, J., et. al. (1999). The Bill of Rights Handbook, Cape Town: Juta and Co Ltd.

Du Plessis, J. V., \& Fouche, M.A. (2006). A practical Guide to Labour Law. Durban: Lexis Nexis Butterworths.

Du Toit, et. al. (1996). The Labour Relations Act, of 1995.

Finnemore, M. (1999). Introduction to Labour Relations in South Africa.

Freeman, R. B., \& Rogers, J. (2006). What workers want, updated edition. Ithaca, N.Y.: ILR Press.

Frontline (2004). Is Wal-Mart a bargain for its workers? Retrieved November 17, 2017, from http://www.pbs.org/wgbh/pagesfrontlines/shows/walmart/transform/employment.html

Grogan, J. (2014). Workplace Law. Cape Town: Juta and Co Ltd.

Gross J. A. (2003). "A long overdue beginning: The promotion and protection of workers' rights" in J.A. Gross (ed) workers' rights as human rights: 1-23 Ithaca, N.Y: Cornell University Press.

Kleiner, M. M. (2001). Intensity of Management resistance: Understanding the decline unionization in the private sector. Journal of Labour Research, 22, 519-40.

Mahiam, E. (1934). The origin of ILO "in the Historical and Social Importance of ILO Legislation, ed, JT Shotwell.

Melita, C., \& Theodore, N. (2005). Undermining the right to organize: Employer behavior during union representation campaigns. Champaign: University of Illinois: Center for Urban Economic Development.

Ramm, T. (1985). The Making of Labour Law in Europe: A Comparative study of Nine Countries. In the Making of Labour Law in Europe ed., Happle, B, C.7, The Hague: Deventer Kluwer. 